\title{
"She Opened Windows": Edna Manley and Jamaican Literature
}

\author{
Edward Baugh \\ Professor Emeritus, UWI
}

\begin{abstract}
Edna Manley has been acclaimed for her contribution to Jamaican culture and social consciousness by way of her work as an artist, mainly in sculpture, and her influence, by example and by guidance, on emerging artists in her time. However, that contribution to the emergence of the "new," pre-Independence Jamaica, must also include what she did for the development of Jamaican literature, although she was not herself a creative writer. In this regard, she made her contribution by way of her influence on, encouragement of, and practical assistance to emerging writers, such as poets H. D. Carberry, A. L. Hendriks, Kenneth Ingram and M. G. Smith, and novelists Roger Mais and Vic Reid. This essay recognizes the roles of her informal soirées at her home. Those writers who did not attend the soirées, would nonetheless seek her comments on their manuscripts. Then there was her founding and editing of the history-making literary journal-anthology Focus. In addition, a few poems by some of the poets were inspired by particular sculptures of hers.
\end{abstract}

Alongside Edna Manley's pivotal role in the development of Jamaican painting and sculpture, for which she is best remembered, is her contribution to the development of Jamaican literature. In this regard, from the late 1930s to the late 1950s, she helped substantively to foster a generative milieu of artistic, intellectual and social consciousness. More particularly, she encouraged individual writers, read and criticized their manuscripts, and published their work or helped to get it published. In these ways she was a moving spirit in the emergence of what we may call modern Jamaican and, by extension, West Indian literature. Her own work as sculptor was an inspiration for some writers. Consequently, her work and theirs embodied the idea of the importance of the cultural and artistic in the emergence of the "new" Jamaica.

The milieu of integrated intellectual, social and artistic consciousness had its nerve centre, so to speak, in the much-talked-about Drumblair soirées at the Manley home. The very fact that this phenomenon has long become legendary no doubt contributes to the difficulty we may now have in trying to establish specifics about it. Which writers, apart from George Campbell, regularly attended these sessions? Ken Ingram, who "was there on quite a few occasions," remembers Vera Bell "and George Campbell, of course."1 Vic Reid said that he was "hardly a part of that group," and his second-hand impression of it was that it was "almost an arty-arty gathering." $\mathrm{He}$ adds that he did "not subscribe to the accusation [my emphasis] that Edna had a 'school,' because with people rambunctious like us you couldn't have a damn school." Indeed, as Mervyn Morris puts it, with reference to an interview with Edna Manley by Easton Lee (April 28, 1981), "she contends that legend has made the Drumblair writers seem more of a formal grouping than was in fact the case."3 
Still, Drumblair the artistic catalyst was a reality, and the informality was no doubt part of its strength. It has even entered Jamaican literature, in a small way, as subject. In a piece entitled "Preliminary Sketch For An Autobiography," broadcast on the BBC Caribbean Voices programme on November 3, 1957, Neville Dawes tells how, as a sixteen-year-old schoolboy at Jamaica College (1942-43), he used to take nightly, solitary walks around Kingston. "Only one adventure," he says, "that approached the marvelous and bizarre is connected with these nightly walks." 4 One night he happened to meet one of his teachers, a Mr. Cohen (the following names are fictitious), who taught Mathematics and Chemistry. Mr. Cohen was on his way to the home of Mr. and Mrs. Raymond Phillips and he invited Dawes to go along with him. “...T. S. Eliot's 'The Rock' was going to be read by a choral-speaking group, and all the important writers, poets and painters in Jamaica would be there ...."

When we arrived at a large house which I guessed was somewhere above Halfway Tree, the performance was about to begin. The guests were seated on the wide veranda in darkness while the choral group stood in the living-room. With infinite grace and instinctive pity, Mrs. Phillips, when I was introduced to her by Mr. Cohen, insisted on my sitting next to her. There was nothing I could reply to her brilliant summing up of the mood and meaning of Eliot's poetry.

I have not been able to confirm the factual basis of this "fragment of autobiography," but until I am corrected, I shall take it at face value. And even if it should prove to be largely fictitious, it seems to me that Drumblair must have provided the basis of the idea.

Dawes goes on to recall that he

Spoke to two poets who had been in the sixth-form during [his] first two years at school. One, who wrote very fragile nature poetry told me he had been struggling against the influence of T. S. Eliot for years. The other, a metaphysical poet who had set the fashion for "padding" out poems with philosophical jargon asked me how was school and did I have any cigarettes ....

Since M. G. Smith was by this time in active service on the battlefront in Europe, one can only guess that the poets may have been Ken Ingram and H. D. Carberry, although Smith is the one whom the phrase "metaphysical poet" brings most to mind. Anyway, Dawes says that he left the party before it was over, and ends:

I walked for what seemed hours before I reached the Constant Spring Road; then, with the pleasure of my introduction to the world of intellectuals sustaining me, I walked the six miles home.

The same episode appeared again, re-worked, in Dawes's first novel, The Last Enchantment (London, 1960). Now the satirical impulse, which had flickered in the original, is dominant. One need conclude no more than that, in this instance, the Drumblair literary evenings provided raw material for Dawes's fiction; but even if we were to believe that he was satirising the actual Drumblair circle, that too, in a sort of backhanded way, would constitute a tribute, and corroborate the importance of those evenings.

Even to those writers, like Vic Reid, who were not members of the Drumblair circle, Edna Manley was accessible, and they sought her advice on their work. In a footnote to The Cultural and Pedagogical Inquiry, Fall 2019, 11(3), pp. 7-12

ISSN 1916-3460 () 2019 University of Alberta http://ejournals.library.ualberta.ca/index.php/cpi/index 
Horses of the Morning, Reid tells of how she "wrote back long detailed appraisals to struggling young writers, as she did to my first full-length novel I sent her in 1939, from the wilds of a west country sugar central where I section-clerked." The "sugar central" was Frome, and the novel, a 60,000 word manuscript, was never published, but Edna's critique gave him heart to continue writing. As he put it, "This was the first encouragement I got."6

Philip Sherlock, who was only two years younger than Edna, speaks of taking "an occasional poem or two" to her. According to him, "she lit a fire in you, ... you didn't go away depressed or anything like that, you went away with something alight inside of you. She opened windows." With regard to Sherlock's well known poem "Pocomania," it is worth noting that it was Edna who took him to the first pocomania meeting which he attended, somewhere off Mountain View Avenue, or Long Mountain Road as it then was. Edna herself did a carving titled "Pocomania" (1936), which may well have prompted Sherlock's poem.

M. G. Smith, H. D. Carberry - one could go on listing other writers who came to notice in the late Thirties and early Forties largely through her encouragement and intervention. Of course, the most celebrated case is that of George Campbell, whose poetry, as George Lamming has reminded us, ${ }^{8}$ became a sort of rallying cry for the new writers of the period, not only in Jamaica but throughout the West Indies.

In Edna Manley: The Private Years (London, 1975), Wayne Brown explains briefly how the relationship between Manley and Campbell began. He quotes at length from a moving letter which the young Campbell wrote to his new friend and mentor, a letter which shows how deeply his talent was to draw on her support. She was to be influential in bringing about the publication of his First Poems (Kingston, 1945), a landmark in the history of West Indian poetry. Nearly forty years later, she was the prime mover behind the Jamaican launch of the Garland new edition (1981) of First Poems, as well as the publication of Campbell's second collection, Earth Testament (Kingston: George Campbell Associates, 1983), which included drawings by her. Her efforts on Campbell's behalf are a signal example of the fact that her belief in a newly-emergent writer always sought to go beyond words of encouragement, and to express itself in as concrete a form as possible.

Her contribution to publication of Campbell's collections may be seen as the peak of the mountain of effort represented by the four issues of Focus that she edited and published (between 1943 and 1960). As Mervyn Morris has written:

Like The Beacon [Trinidad], Bim [Barbados] and Kyk-over-al [British Guiana], Focus published work by a number of writers who are now established figures in West Indian literature: Roger Mais, V. S. Reid, John Hearne, Philip Sherlock, George Campbell, Dennis Scott, A. L. Hendriks, and many others who deserve to be better known ....

What is more, the first two issues of Focus were of seminal importance, containing as they did a distillation of the new spirit of Jamaican writing, driven by the push towards de-colonization and political independence that imbued the late Thirties and the Forties.

And before and behind Focus was Public Opinion. It has not been sufficiently acknowledged how great a contribution this weekly newspaper, founded at the beginning of 1937 by H. P. Jacobs and O. T. Fairclough, and identified with Norman Manley's People's National 
Party - how much of a contribution it made to the development of Jamaican literature and culture, and how significant a part Edna Manley played in this aspect of the paper. She had a hand in rounding up literary material for the paper, and it was she who recruited poet Gloria Escoffery to be literary editor for a short while after Escoffery returned from university in England. Public Opinion was the seed-bed of Focus, at least as far as poetry was concerned. As Ken Ingram, whose poetry appeared in every issue of Focus, said: "All those poems, most of them [in the first two issues], had already appeared in Public Opinion." "10

In this connection, Ingram tells an amusing story which illustrates well certain aspects of Edna Manley's personality. He first met Edna in 1940, through the instrumentality of M. G. Smith, a friend of his from sixth-form days at Jamaica College:

... I was a student-teacher at Wolmer's ... and it was through his showing her some of my poems and she wanted to publish them in Public Opinion; and she was already publishing his in 1940, I'm pretty sure of that ....

He said that his first meeting with her "was very stormy:"

What happened was [that] MG took some poems of mine to her and I didn't know that she was going to publish them and ... [a] poem appeared in Public Opinion in a mutilated form ... and I was mad at it, I didn't like the sort of truncated version, and I suppose -- ... I was far younger then and you don't control yourself in the same way: and I ... remember writing her and being quite annoyed about it, and she drove down to Wolmer's ... [and] she sort of let off at me and said she'd never ever experienced anything like that .... And then I think she wrote me and said we must smoke a peace pipe - would I like to come up - because there were too few of us concerned in the creative effort to be at odds with one another. ${ }^{11}$

And that was how Ingram began attending the Drumblair soirées.

Edna Manley's impact on Jamaican literature involved more than encouragement, guidance and the provision of publishing outlets. Here, we are on ground that is not so easily charted, but to some extent the writing of those early years must have owed something to her in terms of theme and, for want of a better word, attitude. The spirit of the first Focus, which she defined so well in her Foreword - a spirit of serious elation, of breaking chains, of creating a new world, was very much her spirit. But more than that: in ways variously particular or general, conscious or unconscious, some of the poetry, especially that of Campbell and Smith, was inspired by her sculptures.

There is no doubt about Campbell's "Negro Aroused," after Edna's famous carving of the same title; and hardly any more about the connection between his "Tomorrow" and her similarly titled piece. In the latter instance, the inspiration was reciprocal. David Boxer pointed out that a 1939 drawing, "Idyll," bears an inscription, in Edna's hand, which comprises the first two lines of Campbell's "Tomorrow:" "Making it music / Making it sleep and turn" (First Poems, 1945, p. 65). Boxer also noted that three other drawings from the Thirties have holograph inscriptions of lines from three other Campbell poems: "My Love," "Trees" and "I Was Negro." 12 Edna's 1960 water-colour painting "I Saw My Land" illustrates Smith's famous "I Saw My Land in the Morning." 
One thinks also of the kind of poem which seeks, through strong, pared-down symbols, to express a mood and an idea that are at once elemental and quasi-mystical. Various Manley carvings come to mind when one thinks of a poem like Smith's "And Music" or Campbell's "Music" (Focus 1943), or Basil McFarlane's “Ascension" (Focus 1948), just as some of Edna's pieces may be heard as surges of music. When one thinks of her magnificent "The Horse of the Morning", one cannot but hear the opening lines of Smith's "And Music:"

And fine and free the wind

O tameless horse

How human are the hills from which you come

And first and keenest light

My sword

How ancient is the darkness of thy home. ${ }^{13}$

And surely Campbell's "Dawn, O Strange Wild Horse" is his counterpart to "The Horse of Morning:"

Dawn, O strange wild horse

Rushing forth,

Darkness of night in your mane

Wildness of life in your eyes. ${ }^{14}$

The publication of the 1960 Focus more or less marked the end of her vigorous intervention in the literary life of Jamaica, no doubt for various understandable reasons, not least that she had by then accomplished the ground-breaking work that history had called her to do. This does not mean that she stopped taking an interest. Many a young or new writer was to be invigorated by her warm and astute praise. One such is her granddaughter, Rachel Manley, poet, fiction-writer and memoirist.

Edna was overjoyed at the all-too-brief revival of Focus in 1983, edited by Mervyn Morris:

I must write to tell you how happy I am over Focus. Everything about it. The cover, the layout, the paper and the price!! There is some lovely stuff in it don't you think?

Especially the poetry ... For me it is a very moving experience. ${ }^{15}$

In a diary entry for May 31, 1981, she takes a quick, sweeping look at the development of the arts and literature in Jamaica from what she calls "the earnest day" to the time of writing, a look which bespeaks her continuing deep interest in literary developments, but the interest of one now looking from the sideline:

I keep wondering if one had to make a statement, perhaps a speech about Art in Jamaica

"then" and now, how on earth would one handle the subject. Going right back to the ' $30 \mathrm{~s}$ 
when it was all British inspired, to now when some of our artists are fighting to be free from what some call an oppressive nationalism ... Much has been written by writers about the history of writing, and they can handle it with their clear perception. I can only write of the earnest days - times that are often referred to as the battle of the "daffodils and the snow." I know a lot about that - Roger [Mais] and I had our famous "head-on" over that! But since then much that is sophisticated has been written about the place of the Jamaican writer in his confrontation with life "at home and abroad." So let's leave that in their hands. ${ }^{16}$

The posthumous publication of her diaries, edited by Rachel, added a new dimension to her contribution to Jamaican literature. The book claims attention not only for its informative and historical value, but also for its literary quality. In a manner of speaking, she came into her own as a writer, at the last.

\section{Endnotes:}

${ }^{1}$ Ken Ingram, interviewed by Edward Baugh, Nov. 21, 1989.

${ }^{2}$ V. S. Reid, interviewed by Edward Baugh, June 1981.

${ }^{3}$ Mervyn Morris, "Little Magazines in the Caribbean", Bim, Vol. 17, No. 68 (June 1984), p. 7.

${ }^{4}$ Neville Dawes, "Preliminary Sketch for an Autobiography", BBC Caribbean Voices transcripts. University of the West Indies Library, Mona, Box 22.

${ }^{5}$ Victor Stafford Reid, The Horses of the Morning (Kingston: Caribbean Authors, 1985), p. 107.

${ }^{6}$ V. S. Reid, interviewed by Edward Baugh, June 1981.

${ }^{7}$ Philip Sherlock, interviewed by Edward Baugh, December 1982.

${ }^{8}$ George Lamming, address at opening of Edna Manley Retrospective Exhibition, National Gallery of Jamaica, May 30, 1990.

${ }^{9}$ Mervyn Morris, "Little Magazines in the Caribbean", p. 8.

${ }^{10}$ Ken Ingram, interviewed by Edward Baugh, November 21, 1989.

${ }^{11}$ Ibid.

${ }^{12}$ David Boxer, in a lecture given at the National Gallery of Jamaica, September 11, 1990.

${ }^{13}$ Focus (1948), p. 132.

${ }^{14}$ Campbell, First Poems (1945), p. 76.

${ }^{15}$ Edna Manley, letter to Edward Baugh [1983].

${ }^{16}$ Rachel Manley (Ed.). Edna Manley: The Diaries (Kingston: Heinemann, 1989), p. 225. 